\title{
MUSEUM GUNUNG MERAPI (MOUNTAIN MERAPI MUSEUM), A HUMANITARIAN TRAGEDY LANDSCAPE AS A DESTINATION OF DISASTER TOURISM
}

\author{
FX Ari Agung Prastowo ${ }^{1}$, Herlina Agustin ${ }^{2}$, Elnovani Lusiana ${ }^{3}$ \\ $\left\{{ }^{1}\right.$ ari.agung@unpad.ac.id, elnovani.lusiana@unpad.ac.id $\left.{ }^{3}\right\}$ \\ ${ }^{1,2,3}$ Universitas Padjadjaran, Indonesia
}

\begin{abstract}
Yogyakarta has a volcanic mountain that is still active today, Mount Merapi. Its location in the north of the city of Yogya looks very manly even though seen from a distance the south side. The existence of Mount Merapi, which is still active, makes people of Jogja aware and aware of the potential disasters caused. In this regard, the government created the Merapi Volcano Museum (Museum Gunung Merapi/MGM) to increase public knowledge and understanding of volcanoes and other geological disasters. Very interesting collections at the Mount Merapi Museum or MGM include objects affected by the 2010 Merapi eruption, and various kinds of rocks carried by the Merapi eruption, one of which is $65 \mathrm{~mm}$ diameter incandescent rocks. In addition, of course there are tools to detect earthquakes and some volcanic maps in Indonesia, and there are also tools for monitoring volcanic activity. This two-story building clearly presents an integrated knowledge of volcano.By using a qualitative methodology and case study approach, the writing of this article aims to understand the landscape of humanitarian tragedy that was developed into a study of disaster literacy through the media museum as a disaster tourism destination. The author hopes to contribute to the development of similar studies going forward.
\end{abstract}

Keywords:landscape of humanitarian tragedy, disaster literacy, museums, tourist destinations, disaster tourism

\section{INTRODUCTIONS}

The DPR held the World Parliamentary Forum On Sustainable Development in Nusa Dua, Bali, on 6-7 September 2017. The world parliamentary forum was attended by delegations from 47 world parliaments and international observers. A number of strategic agendas were discussed in depth in this forum. Some . "The issues raised in this forum are very relevant with global problems. Humanitarian tragedies in a number of places are still challenges to completely resolved.

Referring to the achievement of SDGs 2030, humanitarian tragedy landscape or the location of natural disasters becomes trends to be a tourist destination and visited by many travelers. As an illustration, in 79 AD, Pompeii was a city of 10 thousand to 20 thousand inhabitants. Located in the Campania region, Italy. It is located southeast of Mount Vesuvius, the only active volcano in Europe. Near Pompeii, there is also Herculaneum, a city inhabited by 4,000-5,000 inhabitants. Herculaneum is located west of Mount Vesuvius and occupies a wider area than Pompeii.

Historically, Vesuvius has erupted 50 times, one of the eruptions occurred in October 79 AD. Live Science said that at that time volcanic ash covered the roofs of residents' homes as 
thick as $15 \mathrm{~cm}$ per hour and made Pompeii dark during the day. Mount Vesuvius then spewed hot clouds following volcanic material that destroyed Pompeii and Herculaneum. Many people died or fled from the two cities. Pompeii was buried in the ground until the city was excavated again in 1748. For more than two centuries, 1,500 victims of a total of 2,000 fatalities due to the natural disaster of the eruption of Mount Vesuvius were found. Finally, archaeologists found the bodies of horse riding in an ancient villa owned by a high-ranking military official. The animal is thought to have died from volcanic ash or hot clouds.

The following buildings and corpses were found and attracted the attention of many people. UNESCO established Pompeii as a world heritage site in 1997. The city is also of interest to tourists. The Guardian noted that nearly 4 million tourists visit Pompeii every year. According to [1], the flow of travelers who come to Pompeii and Herculaneum, makes the city labeled as the oldest disaster tourism site in the world. They say that tourists come there to study history along with various aspects of the activities of Mount Vesuvius. In addition, they can also directly see the human body preserved by volcanic ash.

Based on the explanation above, the writer is interested in studying the situation in Indonesia. The country of Indonesia, is one of the countries in the world that has a high potential for natural disasters. Disaster-prone locations are spread from Sabang to Merauke. Likewise, the humanitarian tragedy began to be framed by the appearance of museums, for example the Tsunami Museum in Aceh and the Mount Merapi Museum (MGM) in Yogyakarta. In this article the author is interested in discussing the uniqueness of MGM.

Yogyakarta has a volcanic mountain that is still active today, Mount Merapi. Its location in the north of the city of Yogya. The existence of Mount Merapi, which is still active, makes Jogja residents aware and aware of the potential disasters caused. In this regard, the government created the Merapi Volcano Museum (MGM) to increase public knowledge and understanding of volcanoes and other geological disasters. Very interesting collections at the Mount Merapi Museum include objects affected by the 2010 Merapi eruption, and various kinds of rocks carried by the Merapi eruption, one of which is $65 \mathrm{~mm}$ diameter incandescent rocks. In addition, of course there are tools to detect earthquakes and some volcanic maps in Indonesia, and there are also tools for monitoring volcanic activity. This two-level of building presents a complete knowledge of volcano.

The data description lead the writer to formulate the problem that will be discussed in a relevant topic, the Merapi Volcano Museum, A Landscape of the Tragedy of Humanity as a Disaster Tourism Destination. This is considered interesting and useful to discuss given the urgency of disaster has become a humanitarian tragedy that goes beyond national borders. Inevitably the occurrence of disasters in an area can have a wide impact across national borders. Therefore, there needs to be attention and care especially from academics to expand this disaster-related study. The disaster tragedy landscape has opportunities and challenges to provide educational benefits in the field of disaster literacy for the community. However, the potential for exploitation in disaster tourism should also be avoided so that it does not happen.

\section{LITERATURES REVIEWS}

Several approaches are used to analyze the topic of this study. In a study entitled "Dark Tourism: Concepts, Typologies, and Sites [1] said disaster tourism is a specific part of dark tourism. Dark tourism refers to the activity of visiting a place filled with sadness, distress, cruelty, and pain. They say the typology of dark tourism there are various kinds, depending on the motivation of visitors and the site. 
According to Fonseca, Seabra, and Silva, there are six types of dark tourism, including disaster tours, war tours, prison tours, funeral tours, ghost tours, and Holocaust tours. The practice of traveling to a place that has recently experienced a natural or man-made disaster is called disaster tourism. Meanwhile, [2] "Dark Tourism and Disaster Tourism" defines disaster tourism as a type of tourism born after or due to natural disasters as well as traumatic events. Examples of disaster tourism, he continued, include places like the World Trade Center in New York City and flood-affected areas in New Orleans after Hurricane Katrina.

Brigitte Sion, a researcher affiliated with Columbia University and editor of the book Death Tourism: Disaster Sites as Recreational Landscapes [3]. explains that there are various reasons that encourage people to visit a former disaster or tragedy. According to him, some visitors have connections with events because he is a survivor, witness, or relative of a disaster victim.If it is related to the educational benefits of humanitarian landscape view, this paper needs the concept of disaster literacy to strengthen the analysis in the discussion section. The presence of disaster tourism not only strengthens the opportunity of increasing the number of visits of tourists who are interested in coming to visit, the opportunity to disseminate the benefits of education is wide open.

Indonesia as a disaster-prone country requires more in-depth disaster studies as part of the development of disaster risk reduction. Many streams of disaster studies are developing now, which in its approach falls into two major paradigms, namely structural and non-structural approaches. Disaster literacy is part of a non-structural approach that focuses on skills and understanding of disasters. Disaster literacy is a study that is still considered new in disaster studies, while disaster literacy can be an offer for disaster studies, especially concerning the measurement or building of community capacity for disasters. Disaster literacy studies focus on how the community's level of understanding and critical power is related to disaster [4].

\section{METHODOLOGY}

The writing method used in this study is descriptive qualitative. In-depth analysis is carried out referring to the use of literature, official documents and field research (observation) as well as interviews with several informants. The case study approach is also expected to increase the sharpness of the analysis of the study of the Mount Merapi Museum (MGM), as a disaster tourism destination in the context of disaster literacy.

\section{RESULT AND DISCUSSIONS}

The history of the founding of the Mount Merapi Museum or abbreviated as MGM can be found on the [5]. The building which stands on an area of 3.5 hectares reaches 4470 square meters, which was once initiated by the Center for Volcanology and Geological Disaster Mitigation, Geological Agency, Ministry of Energy and Mineral Resources. The construction of the museum is based on regulations and mutual agreement between the central government in this case the Directorate General of Energy and Mineral Resources, Yogyakarta Special Province, and Sleman Regency. The cone-shaped building that resembles a volcano is built in accordance with philosophy and culture that is adapted to local custom rules.

The Mount Merapi Museum was inaugurated on October 1, 2009 by Purnomo Yusgiantoro who at that time served as Minister of Energy and Mineral Resources. The museum is a means of education, as a medium of information, education and tourism, especially in the aspects of volcano science. This is in accordance with the condition of Indonesia which is located in the ring of fire and is rich in volcanoes. By disseminating volcanic information and other 
recreational and educational geological disasters, the goal can be achieved to provide insight and understanding of the scientific, and socio-cultural aspects related to volcanoes, especially about Mount Merapi. The existence of the Mount Merapi Museum is expected to be an important tool in the effort to educate the nation, as well as in the development of educational tourism, especially in the Special Region of Yogyakarta. Aside from being a center for volcano information services, it is expected to become a medium for the community to increase public awareness and alertness in particular in the environment of volcanic-prone areas about the benefits and threats of volcanic eruptions.

When examined in the study, [1], said disaster tourism is a specific part of dark tourism. Dark tourism refers to the activity of visiting a place filled with sadness, distress, cruelty, and pain. Based on the author's experience of observing several visitors who were interviewed, it was clearly revealed the success of MGM in revealing the experience of deep sadness from past events. The average visitor feels what happens complete with the depth of emotion when searching various artifacts that are displayed nicely and interestingly. A deep impression coupled with an emotional touch makes sure visitors or tourists want to return to visit MGM by inviting relatives, friends or relatives who have never been to MGM to participate in the same inner experience.

One visitor, an elementary school age child, named Arliva who was interviewed by the author revealed that he felt the aura of sadness experienced by the victim while walking down the display of artifacts at MGM. Arliva revealed that his visit to MGM has increased his knowledge and interest to invite his friends to visit MGM and feel the benefits as his personal experience.

Fonseca, Seabra, and Silva identified six types of dark tourism, including disaster tours, war tours, prison tours, funeral tours, ghost tours, and Holocaust tours. According to Kevin Fox Gotham in "Dark Tourism and Disaster Tourism" defines disaster tourism as a type of tourism born after or due to natural disasters is also a traumatic event [2]. The practice of traveling to a place that has recently experienced a natural or man-made disaster is called disaster tourism.

Other disaster tourism destinations, which also support MGM's educational efforts, are Lava Tour attractions located on Mount Merapi. Zein Mufarrih Mukraf in "Disaster Tourism: A Case Study of the Mount Merapi Lava Tour" [6] explains that Mount Merapi, which lies between Central Java and Yogyakarta, is the most active mountain on the island of Java. Mount Merapi last erupted in 2010 and spewed 140 million $\mathrm{m} 3$ of volcanic material. Lava Tour, continued Zein, is one of the tourist attractions offered by the community on the slopes of Mount Merapi. There are several destinations that can be visited on the Lava Tour, including Kali Adem Bungker, Batu Alien, Mbah Maridjan, Eating Mbah Maridjan, and the Sisa Hartaku Museum. By riding a jeep, tourists will be invited to visit the above places while feeling the off-road sensation at Kali Kuning.

"Another visitor who was interviewed by the writer, named Zahra, has a cultural and intellectual interest. Zahra said his desire to understand what happened and find out the relationship of tragedy with other historic events. In addition, there are also people who do not have any connection to the place or event but come there as tourists and aim for recreation, for example a visitor named Vina. He said casually that he only joined a family who travel together without having a specific purpose in visit MGM.

Regarding the eruption of Mount Merapi in 2010, Zein said, "Disaster tourism is concretely part of community resilience. With the construction of disaster tourism destinations, the community can survive and rebuild their lives independently. "Disaster tourism, 
reconstruction, and resilience are interrelated," he explained. The researcher from Yogyakarta Muhammadiyah University, explained that tourists would receive information about matters related to the eruption of Mount Merapi. According to Zein, if it is equipped with the mastery of information related to Mount Merapi and the impact of eruptions can be a way to provide disaster literacy to tourists. Moreover, disaster tourism prioritizes interactions between witnesses to events and tourists.

Furthermore Kevin Fox Gotham looked at it from a different perspective. According to him, this type of tourism is often seen as exploiting, insensitive, and voyeuristic alias makes the distress of others as a source of personal pleasure. In addition, disaster tourism is also seen as a form of profit dredging by capitalizing the victims' misfortune. But, Gotham said that there are those who judge disaster tourism as beneficial because it can be used for educational facilities. This conclusion he got after doing research on the Lakeview community in New Orleans, United States, which fell victim to Hurricane Katrina in 2005. According to Gotham, tourism in Lakeview is a subtle critique aimed at raising global awareness of disasters. In addition, disaster tourism is also used to attract people's empathy and gather public support so that the disaster site is restored.

Brigitte Sion, a researcher affiliated with Columbia University and editor of the book Death Tourism: Disaster Sites as Recreational Landscapes [3], explains that there are various reasons that encourage people to visit a former disaster or tragedy. According to him, some visitors have connections with events because he is a survivor, witness, or relative of a disaster victim.

As stated by one of the officials in Sleman Regency who is responsible for the existence of MGM, he explained that the Merapi Volcano Museum is a historic museum that can be used as a means of education, dissemination of information on aspects of volcano in particular and other geological disasters that are recreational-educative for the wider community with the aim of to provide insights and understanding about scientific aspects, as well as socio-cultural and others related to volcanoes and other sources of geological disasters. The Volcano Museum is expected to be an alternative solution as a very important and potential tool as a center for volcano information services in an effort to educate people's lives, as well as a media in raising public awareness and awareness about the benefits and threats of volcanic eruptions and other geological disasters.

Indifference born from a lack of understanding of the meaning of disaster and its mitigation, poses a great risk to the fall of disaster victims. So, this education should be a program that is continuously carried out in order to become habits (positive habits) of the community that are carried out consciously and massively. Mount Merapi Museum is one of the places that serves as a means of disaster literacy about the most active mountains in the world. In this museum, tourists can learn about Mount Merapi from the side of legends and myths, local wisdom, eruption history, and see the remnants of a stifling eruption.

As an area of ring of fire, Indonesia has hundreds of mountains that stretch from Sumatra to Papua, both inactive mountains to mountains that are still turbulent. Mount Merapi is one of the most active mountains in Indonesia, even in the world, located on the border of Central Java and Yogyakarta Special Region. This makes the area included in disaster prone areas. The development of MGM is an anticipatory step to provide an understanding of the importance of disaster mitigation efforts. Besides functioning as an alternative educational tourism for students and the wider community, globally, the Merapi Volcano Museum also aims as a place for the development of the science of volcanic disasters, earthquakes, and other natural disasters.

Carrying the slogan "Merapi Jendela Bumi", the Merapi Volcano Museum is divided into two floors. Entering the first floor, tourists are immediately greeted with education using a large model of Mount Merapi that rumbles and emits smoke. On one side is the year button which is 
the year of eruption. If one button is pressed there will be an eruption demonstration in the form of a molten lava melt simulation and narration with Javanese music background.

From this main room tourists can continue their journey to the volcano world zone. In this zone there are documentation and props about the volcano phenomenon that exist throughout the world. In each display there are information boards in two languages making it easier for tourists to understand even if they are not accompanied by a guide. After that there is a special zone of Mount Merapi which contains the ins and outs of Merapi. In this zone, tourists can witness the phenomenon of the growth of the Mount Merapi dome, myths about Mount Merapi, Mount Merapi observation posts from the Dutch era to the modern era, and much more.

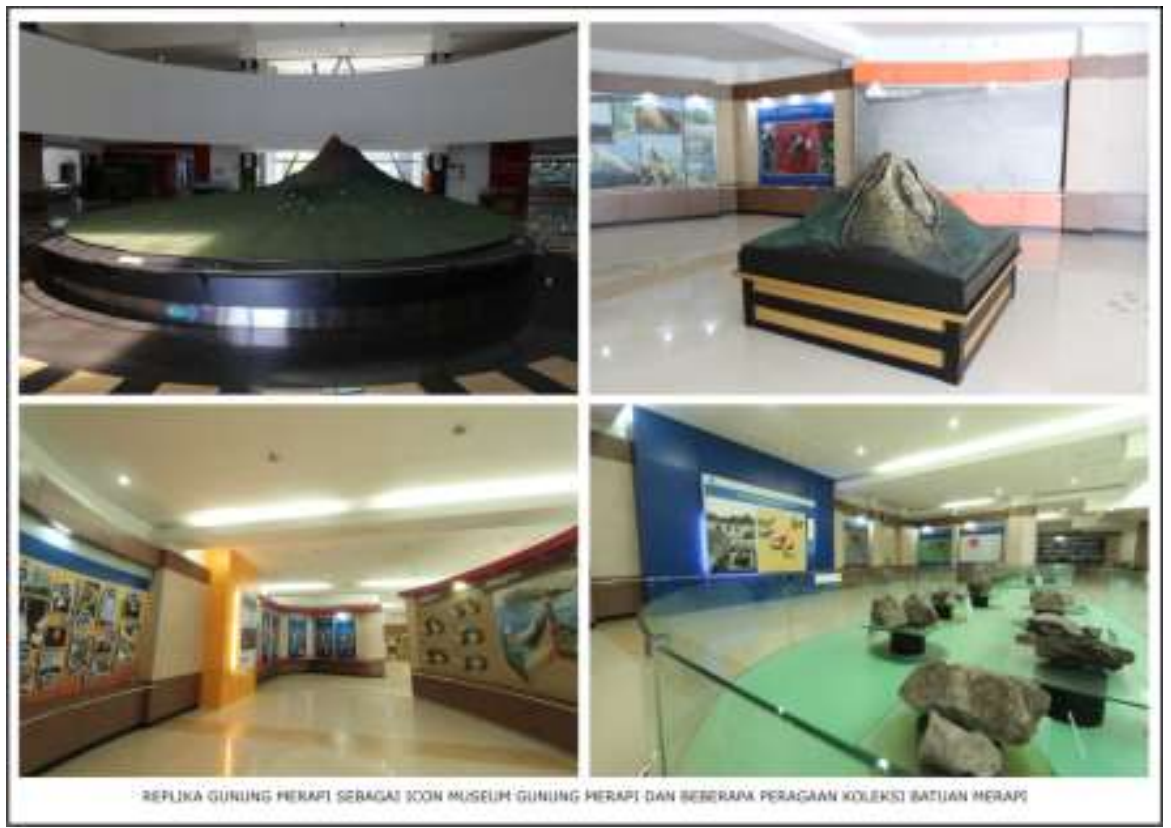

Source : [5]

Satisfied down the first floor, tourists can go up to the second floor to watch the props of the tsunami and photos of the eruption. Tourists can watch the Merapi eruption documentation from 1930 to 2010 . Not only that, in the zone also shown how to save themselves from the threat of volcanic eruptions. Therefore, it seems quite reasonable and not excessive if MGM is used as a vehicle for mitigation education to reduce the number of fatalities. On the second floor there is also a mini theater with a capacity of 100 people who broadcast a 20-minute documentary "Under the Sky Merapi" 


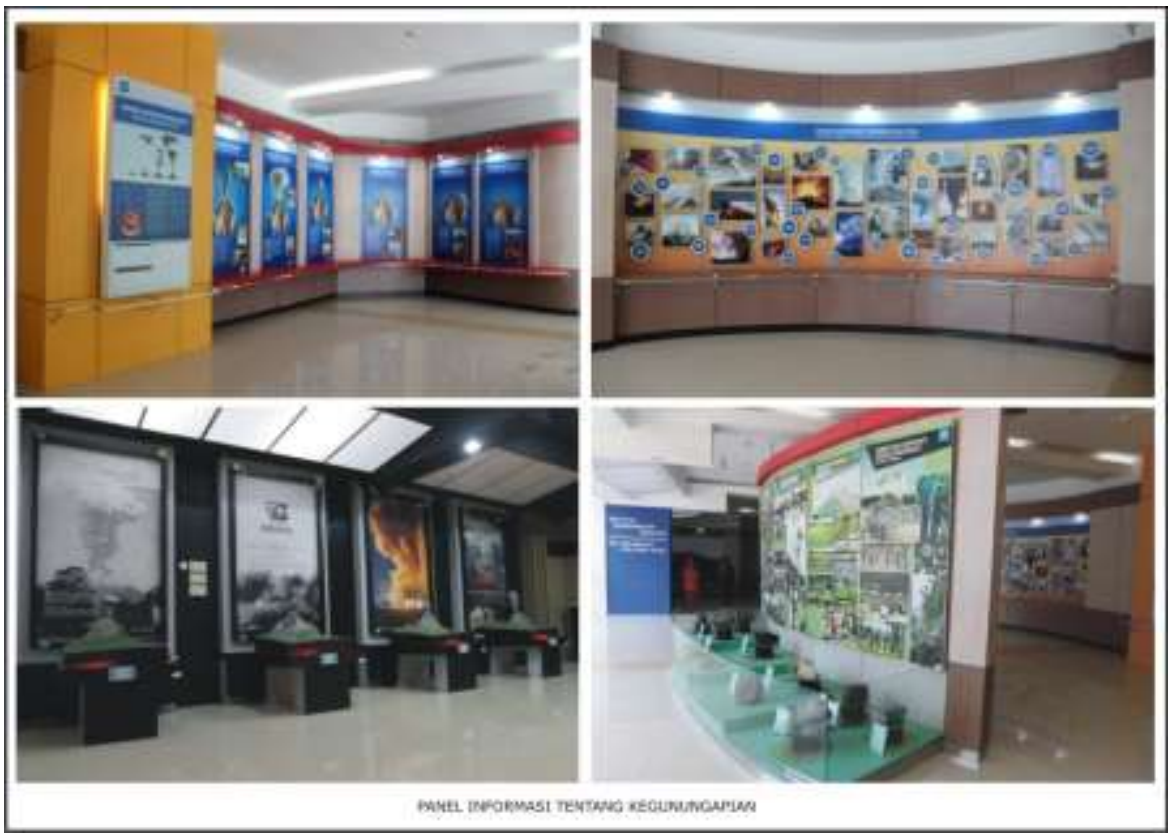

Source : [5]

The Merapi Volcano Museum (MGM), which is planned to become a geo-tourism in DIY, is expected to be a vehicle for sustainable conservation education and the development of science of volcanic disasters, earthquakes and other natural disasters. MGM location is located on the slopes of Merapi, precisely in Boyong Street, Banteng Hamlet, Hargobinangun Village, Pakem District, Sleman Regency. This venue wants to be known by the public as 'Merapi Volcano Museum, Merapi Jendela Bumi'.

The Volcano Museum can be used as a media for disaster literacy through the dissemination of information on volcanic aspects in particular and other geological disasters that are recreational-educative for the wider community with the aim of providing insight and understanding of scientific, as well as socio-cultural and other aspects relating to volcanoes and other sources of geological disaster. The Mount Merapi Museum is expected to be an alternative solution as a very important and potential tool as a center for volcano information services in an effort to educate people's lives, as well as a media in raising public awareness and alertness about the benefits and threats of volcanic eruptions and other geological disasters.

Referring to the description of the results of the discussion and discussion, there are at least four things why disaster literacy is very crucial, especially for people living in disaster prone areas. First, provide basic knowledge about disaster. Lack of understanding of the meaning of disaster causes some people are not ready and not prepared for the possibility of a disaster coming.

They just follow the natural destiny and don't want to bother with disasters. This apathy will obviously be detrimental to the community itself because they will bear the risk of disaster. Therefore disaster education is very necessary to be done so that people have an open mindset of the information and disaster data they obtain. So, slowly, the community began to realize the importance of disaster preparedness. 
Second, disaster education can provide responsive motivation and enthusiasm to the community in dealing with disaster situations. When people begin to understand and take part in disaster preparedness, they will be collegially motivated to get together to be alert and take steps to anticipate disasters in their areas.

Third, disaster education is able to glue social solidarity. With disaster education a sense of shared social responsibility is raised without distinction of social strata so that it can last a long time and be sincere. In a disaster situation, of course, each individual community bears responsibility for their own safety. However, with disaster education, a sense of social responsibility is also strengthened so as not to appear indifferent to the problems experienced by other community members. Without disaster education that teaches a sense of togetherness it would be difficult to build empathy for others.

Fourth, disaster education is expected to reduce the impact and minimize casualties. Understanding and simulating disasters given during disaster education is expected to increase knowledge and responsive attitudes when disasters actually occur so as to reduce the loss of lives.

Without adequate knowledge and simulation, impact and loss of life are very difficult to suppress. Therefore, disaster tourism as a medium for disaster literacy is a conditio sine qou non, especially for the community so that they have stock and a thorough understanding in anticipating the coming of a disaster.

\section{CONCLUSSIONS}

The presence of the Merapi Volcano Museum (MGM) as a disaster tourism destination, has significantly increased public knowledge and understanding of volcanoes and other geological disasters. Various interesting collections of artifacts from the tragedy landscape of humanity present a complete knowledge of volcano. The discussion in this article has succeeded in uncovering a finding that MGM as a disaster tourism destination can bridge the understanding of the humanitarian landscape that was developed into a study of disaster literacy through museum media. Disaster literacy itself can be interpreted as all efforts, methods, and operations to provide knowledge, understanding, and positive attitudes of the community towards disaster situations so as to create a sense of knowledge and proportional attitude in dealing with disaster hazards. In the end, disaster literacy is a necessity. This disaster tourism is very closely related to Indonesia's geographical conditions which are very prone to disasters such as earthquakes, volcanic eruptions, floods, and so on. With the situation, conditions and facts, this disaster literacy becomes very important. Anticipatory and participatory attitudes are the key to success in educating the public about the dangers of disasters.

So far, the community is only given a warning if a disaster comes without adequate educational efforts regarding preparedness measures and procedures for dealing with the disaster. Disaster literacy using museum media as a disaster tourism destination is considered very important for mental preparation and public awareness in carrying out rapid actions during and after disasters occur. Education can also minimize casualties because the community will gain an understanding of saving lives when a disaster occurs.

Natural disasters that cause thousands of people to die like earthquakes need to be understood by the public. So that they are able to detect what actions can be taken when the disaster comes. Disaster literacy allows each member of the community to take responsive rescue measures that at least can avoid the danger of disaster. 


\section{REFERENCES}

[1] A. P. Fonseca, C. Seabra, dan C. Silva, "Dark Tourism: Concepts, Typologies and Sites," J. Tour. Res. Hosp., vol. 1, no. 1, 2016.

[2] K. F. Gotham, "Dark Tourism and Disaster Tourism," Wiley Online Libr., 2015.

[3] B. Sion, Death Tourism: Disaster Sites as Recreational Landscape. English: Seagull Books, 2014.

[4] Z. M. Muktaf, "Studi Literasi Bencana dalam Perspektif Ilmu Komunikasi," 2017.

[5] "Museum Gunung Merapi," 2015. [Daring]. Tersedia pada: http://museum.geology.esdm.go.id/museum-gunung-merapi.

[6] Z. M. Muktaf, "Wisata Bencana: Sebuah Studi Kasus Lava Tour Gunung Merapi," Pariwisata, vol. IV, no. 2, hal. 84-93, 2017. 